Despite the 7 July terror attacks in London, last week's meeting of the Group of Eight industrialized nations remained focused on its two priorities: Africa and dimate change. The outcome has left most observers somewhere between disillusion and cautious optimism.

Expectations that the G8 summit would mark a clear turning point in combating climate change or in strengthening science and technology in Africa have clearly not been met (see page 151). But the meeting, held in Gleneagles, Scotland, from 6 to $8 \mathrm{July}$, created political commitments that may yet yield progress and turned a global spotlight on to Africa.

The communiqué about Africa, signed by world leaders at the summit's close, included measures on debt relief for the poorest countries, funding to combat disease, and a new commitment to double aid to Africa by 2010. But it left key issues dangling on trade and aid, and science was relegated to a back seat.

Hopes that the summit would focus strongly on science and technology were raised by the Commission for Africa, a group of 17 world leaders and heads of UN agencies, whose March report made a strong case for more G8 spending on building science and technology capacity, and training in Africa. The commission suggested donors spend US $\$ 3$ billion over the next decade to create centres of excellence, and allot $\$ 500$ million every year, for ten years, to reinforcing African universities.

\section{Promises, promises}

There are no such specifics in the G8 communiqué. There is, however, a commitment to centres of excellence to help develop skilled professionals, although there is no promise of money nor any clear indication of what such a commitment would mean. This signals an important change, according to Brian Greenwood, director of the Malaria Centre at the London School of Hygiene and Tropical Medicine. "I like the emphasis on investing in people, rather than just on the tools as many other major donors have tended to do, he says.

The summit was more forthcoming on the problem of neglected diseases. It promised to replenish the near-empty coffers of the Global
Fund to Fight AIDS, Tuberculosis and Malaria. "I'm glad. I think this is probably the best vehide for ensuring sustainable and successful healthcare interventions in Africa," says Richard Tren, director of Africa Fighting Malaria, a pressure group based in South Africa and the United States.

The summit also endorsed universal access to HIV treatment by 2010 , adding that it would "support" meeting the $\$ 829$-million costs of the Global Polio Eradication Initiative from 2006 to 2008 , although it didn't actually commit to giving any money.

\section{Trade-offs}

The G8 also agreed, in principle, to incentives for vaccine and drug research on malaria, tuberculosis and other diseases that offer few profits. These include 'advance purchase commitments' in which governments promise to buy, for example, agreed quantities of a malaria vaccine that meets certain performance characteristics. ${ }^{\alpha}$ This is an important development," says Adrian Hill, a malaria-vaccine researcher at the University of Oxford, UK.

Hill adds, however, that he has concerns about how these initiatives would work in practice, and whether they would encourage new companies to enter the field of neglected diseases. He also regrets the lack of direct funding for research on the development of malaria vaccines and says he wanted to see something like the Global HIV Vaccine Enterprise endorsed by 2003's G8 summit. ${ }^{\alpha}$ That led to hundreds of millions of new dollars of HIV vaccine funding from the US National Institutes of Health and the Gates Foundation."

Discussion of easing or scrapping the trade restrictions on Africa, which many feel are the biggest single obstacle to the continent's development, has been postponed until December's World Trade Organization talks in Hong Kong. The summit also failed to clear any debts between individual nations, agreeing only to cancel the debts of the 18 poorest countries to international donors, such as the International Monetary Fund.

In terms of aid, the summit said that growth in spending by G8 and other donors, including commitments made in the run-up to the summit, is already on track to double aid for Africa to $\$ 50$ billion annually by 2010 . Britain's proposal for an International Financing Facility, designed to immediately ramp up aid, was diplomatically sidelined as a project that some G8 members believed in, and would continue to consider.

Despite the lack of specific commitments, many observers feel that the G8 got the big picture right. ${ }^{\alpha}$ The best news was probablythe high-profile attention given to the problems of Africa and the priority that this now has on the world stage," says Hill. "Hopefully this will not be a one-off. These are huge long-term problems that will require continuing attention at the highest level."

Tren also praises the summit's "strong and repeated messages" that development must be African-led, and that African countries must adopt sound policies for growth and economic development. This echoes calls from African scientists and politicians, published in Nature, saying that projects should be run as far as possible by Africans, not donors (see Nature 435, 1146-1149; 2005).

\section{Climate of change}

The outcome of the climate-change debate was similarly mixed. In a separate communiqué issued on $8 \mathrm{July}$, the G8 leaders acknowledged that "climate change is a serious andlong-term challenge that has the potential to affect every part of the planet.

As expected, the document highlights remaining scientific uncertainties. Nonetheless, the G8 leaders, including US president George W. Bush, agreed that human activities "contribute in large part to increases in greenhouse gases.' A list of 38 action points includes the promotion of low-emitting energy systems and vehicles, and a number of market-led approaches aimed at encouraging investment in clean technologies.

The eight nations also promised to start a dialogue with newly emerging economic powers, the G5, about tackling, and adapting to, global warming. The G5 comprises China, India, South Africa, Mexico and Brazil.

Policy analysts say that the most visible success of the meeting was the Bush administration's first public concession that climate change is a real and predominantly man-made threat. However, the noncommittal wording of 
the communiqué caused widespread disappointment. "The conspicuous failure of the G8 explicitly to mention even the need for targets to reduce emissions of greenhouse gases underlines our concern," says Robert May, president of the Royal Society in London.

\section{Sumit up}

The G8 is an informal forum that cannot produce a legally binding treaty. But, says Tom Downing of the Stockholm Environment Institute's Oxford office, the group does have the potential to bring together cities, communities and businesses in the world's richest nations. So he is disappointed that there was no mention in the climate communiqué of how cities and communities might contribute to protection on a regional scale. ${ }^{\alpha}$ The G8 leaders failed to realize this potential, ${ }^{p}$ he says. "They basically ignored the policy mandate they were given."

Other climate experts are less harsh. ${ }^{\alpha}$ The substance of the communiqué is better than its rhetoric," says Michael Grubb, an expert on climate change and energy policy at Imperial College London. "I don't think the meeting was a failure. No one ever expected anything with specific numbers attached to it anyway."

One reassuring signal, he says, is the unambiguous reassertion that the UN Framework Convention on Climate Change is the appropriate arena for discussing a binding climate agreement. The G8 also welcomed Japan's offer to receive a progress report on climate change at the summit it will host in 2008. That's by no means an attempt to sideline the UN, says Grubb. Instead, he believes it indicates that the richest countries, including the United States, have seriously begun to seek a way out of the mess in which climate negotiations have become mired.

What has been lacking in recent years, Grubb says, is a structured discussion that includes both the United States and developing countries. "Now we have a dub of 13 core countries, representing the world's major power and population centres, who can attempt to negotiate a feasible climate strategy. This is a quite significant advance."

The meeting may also have provided the first tentative moves towards getting the United States to support the Kyoto Protocol, some analysts believe. The Bush administra- tion withdrew from the protocol in 2001, saying that it would damage the US economy. But the G8's communiqué and action points indude hints that the country may be prepared, in the mid-term, to revise its course, says Axel Michaelowa, head of dimate policies at the Hamburg Institute of International Economics in Germany.

One such signal, he says, is the commitment to adequately fund by the end of 2005 the executive board that oversees the implementation of the Kyoto Protocol's Clean Development Mechanisms. These are measures in which rich countries or industries can buy emission rights if they supply expertise that reduces greenhouse-gas emissions in developing countries. Strengthening technology and market-led approaches in a post-2012 UN dimate agreement could get the United States back on board, points out Michaelowa.

"No doubt Bush has left himself a way out," he says. "But the G8 statement includes concessions on the part of the United States that do give hope"

Declan Butler and Quirin Schiermeier 